\title{
Faktor-Faktor yang Mempengaruhi Investasi Swasta di Indonesia
}

\author{
Adrian Sutawijaya \\ Universitas Terbuka \\ J1. Raya Pondok Cabe, Pamulang, Tangerang Selatan 15418 \\ E-Mail: adrian@ut.ac.id \\ Zulfahmi \\ Universitas Terbuka \\ J1. Raya Pondok Cabe, Pamulang, Tangerang Selatan 15418 \\ E-Mail: fahmi@ut.ac.id
}

\begin{abstract}
Exports and investment play an important role in the economy of a country that is open. Exports will generate foreign exchange, foreign exchange to finance imports of capital goods and raw materials required in the production process that will create added value for the economy. The variables examined in this study is the difference in private sector investment plans, loan interest rates, government spending, and Gross Domestic Bruto (GDP). Research on the analysis using the method of least squares OLS (Ordinary Least Square). Results of regression test based on the theory, statistical and econometric criteria. The results of this study are interest rates significantly have a positive affect on the private investment. GDP will have a positive effect on investment and also government spending has a positive effect on private investment.
\end{abstract}

Keywords: interest rates, GDP, government spending.

\begin{abstract}
ABSTRAK
Ekspor dan investasi memainkan peran penting dalam perekonomian suatu negara yang terbuka. Ekspor akan menghasilkan devisa, devisa akan digunakan untuk membiayai impor barang modal dan bahan baku yang diperlukan dalam proses produksi yang akan menciptakan nilai tambah bagi perekonomian. Variabel yang diteliti dalam penelitian ini adalah perbedaan dalam rencana investasi sektor swasta, suku bunga kredit, pengeluaran pemerintah, dan PDB. Penelitian di analisis dengan menggunakan metode OLS kuadrat terkecil (Ordinary Least Square). Hasil uji regresi didasarkan pada teori, statistik kriteria dan ekonometrik. Hasil dari penelitian ini adalah faktor suku bunga akan berpengaruh terhadap investasi swasta sebesar ke 5280 miliar. PDB akan memberikan efek positif pada investasi dan juga pengeluaran pemerintah memiliki pengaruh positif pada investasi.
\end{abstract}

Kata Kunci: suku bunga kredit, PDB, pengeluaran pemerintah. 


\section{PENDAHULUAN}

Ekspor dan investasi memegang peran penting dalam perekonomian suatu negara yang terbuka. Ekspor akan menghasilkan devisa, devisa akan digunakan untuk membiayai impor bahan baku dan barang modal yang diperlukan dalam proses produksi yang akan membentuk nilai tambah bagi perekonomian. Agregasi nilai tambah yang dihasilkan oleh seluruh unit produksi dalam perekonomian merupakan Produk Domestik Bruto.

Investasi atau penanaman modal adalah komponen pembentuk nilai tambah nasional, yang merupakan pembelian barang modal dan pelengkapan produksi untuk menambah kemampuan memproduksi barangbarang dan jasa yang tersedia dalam perekonomian. Meningkatnya kegiatan perekonomian sangat tergantung kepada aliran modal bagi usaha produktif. Ada sementara ahli yang mengatakan bahwa ekspor dan investasi merupakan "engine of growth". Oleh karena itu, tingkat pertumbuhan ekonomi yang tinggi dan berkesinambungan pada umumnya didukung oleh peningkatan ekspor dan investasi.

Teori ekonomi mendefinisikan investasi sebagai pengeluaran-pengeluaran untuk membeli barangbarang modal dan peralatan-peralatan produksi dengan tujuan untuk mengganti dan terutama menambah barang-barang modal dalam perekonomian yang akan digunakan untukmemproduksibarang dan jasa di masa yang akan datang. Dengan perkataan lain, investasi berarti kegiatan perbelanjaan untuk meningkatkan kapasitas produksi sesuatu perekonomian (Sasana, 2008)

Penanaman modal merupakan langkah awal kegiatan pembangunan, investasi pada hakikatnya merupakan awal kegiatan pembangunan ekonomi. Dinamika penanaman modal mempengaruhi tinggi rendahnya pertumbuhan ekonomi. Urgensi tentang pembentukan modal di daerah mendapat perhatian dan penekanan oleh Zaris (1987) yang menyatakan bahwa investasi swasta memainkan peranan penting dalam membentuk pola pembangunan di daerah. Investasi ini akan menyebabkan terbentuknya modal daerah (regional capital formation).

Dari berbagai teori ekonomi menjelaskan bahwa investasi merupakan fungsi dari tingkat bunga. Meningkatnya tingkat bunga akan mengakibatkan berkurangnya pengeluaran investasi, dan sebaliknya menurunnya tingkat bunga akan mengakibatkan bertambahnya pengeluaran investasi. Sukirno (1994) mengatakan bahwa tingkat suku bunga adalah faktor yang menentukan besar kecilnya investasi yang dilakukan oleh masyarakat (swasta). Menurunnya tingkat suku bunga akan menaikkan permintaan investasi. Suku bunga yang tinggi dapat merupakan hambatan bagi pertumbuhan sektor swasta maupun publik. Oleh karena itu suku bunga rendah merupakan syarat penting untuk mendorong investasi swasta.

Beberapa penelitian terdahulu tentang investasi swasta yang telah dilakukan yakni oleh Radianto (1995) yang menunjukkan bahwa variabel PDRB dan variabel tingkat suku bunga tidak mampu menjelaskan fenomena investasi swasta di Maluku, hanya variabel angkatan kerja yang mampu menjelaskan variasi investasi swasta. Dalam penelitian Kodoatie (1998) variabel penanaman modal tahun sebelumnya, pertumbuhan ekonomi, belanja pembangunan, nilai tukar, dan kebijaksanaan reformasi di bidang investasi berpengaruh terhadap PMA. Teori Investasi NeoKlasik menunjukkan bahwa tingkat pertumbuhan PDB riil berpengaruh positif terhadap investasi swasta (Wai and Wong, 1982; Greene dan Villanueva, 1991; Fielding, 1997). Hal ini juga dikenal sebagai "efek akselerator" (Ouattara, 2000). Selain itu, nilai modal yang diinginkan oleh sebuah perusahaan berpengaruh secara positif pada tingkat permintaan (Bayai dan Nyangara, 2013).

Pendapatan nasional merupakan jumlah barang dan jasa yang dapat dihasilkan oleh perekonomian suatu negara pada satu periode, di mana tingkat pendapatan nasional yang tinggi mencerminkan jumlah barang dan jasa yang dihasilkan oleh perekonomian tersebut bertambah banyak. Untuk mencapai tingkat pendapatan nasional yang tinggi maka perlu dicapai terlebih dahulu tingkat kesempatan kerja yang tinggi dan peningkatan kapasitas produksi nasional yang tinggi. Dengan kata lain bahwa dengan tercapainya tingkat kesempatan kerja yang tinggi berarti kapasitas produksi nasional berada dalam pemanfaatan penuh. Salah satu komponen produk nasional yang dilakukan oleh perusahaan adalah pengeluaran investasi (investment expenditure) sehingga investasi merupakan fungsi dari pendapatan nasional. 
Beberapa penelitian lainnya tentang investasi swasta memasukkan unsur pengeluaran pemerintah sebagai faktor penentu besar kecilnya investasi swasta di suatu negara (Sakr, 1993; Haque, Husain, dan Montiel, 1991; Naqvi, 2002; Ahmad, Imtiaz, dan Qayyum, Abdul, 2008). Penelitianpenelitian tersebut menunjukkan hasil bahwa terdapat hubungan positif antara pengeluaran pemerintah dengan investasi swasta.

Berdasarkan uraian tersebut, maka yang menjadi pokok permasalahan dalam penelitian ini adalah faktor-faktor apa saja yang mempengaruhi investasi swasta di Indonesia, dengan tujuan dari penelitian ini adalah untuk menganalisis faktor-faktor yang mempengaruhi investasi swasta di Indonesia.

\section{METODE}

\section{Jenis dan Sumber Data}

Dalam penelitian ini variabel dependen yaitu selisih penanaman modal langsung yang terjadi di dalam negeri yang di dapat dengan mengurangi rencana penanaman modal dalam negeri $(\mathrm{Rp})$ tahun $\mathrm{n}$ dan penanaman modal asing (dirupiahkan dengan kurs berlaku) dengan realisasinya pada tahun $\mathrm{n}_{+1}$. Proksi ini dilakukan untuk menggambarkan lag rencana dengan realisasi karena ternyata cukup bervariasi.

\section{Variabel Independen}

\section{Tingkat Suku Bunga Kredit (SBK)}

Tingkat suku bunga merupakan suatu jumlah yang diterima atas penggunaan sejumlah uang yang dipinjam untuk membiayai suatu keperluan tertentu dalam jangka waktu tertentu oleh pihak lain . Tingkat suku bunga dalam negeri diproksi dengan tingkat suku bunga kredit pada bank-bank umum yang dinyatakan dalam persen.

\section{Produk Domestik Bruto (PDB)}

PDB merupakan nilai dari akhir keseluruhan barang/jasa yang dihasilkan oleh semua unit ekonomi dalam suatu negara, termasuk barang dan jasa yang dihasilkan warga negara lain yang tinggal di negara tersebut.

\section{Pengeluaran Pemerintah (PP)}

Pengeluaran Pemerintah merupakan variabel yang menggambarkan pengeluaran oleh Pemerintah untuk menjalankan roda pembangunan. Dalam penelitian ini Pengeluaran Pembangunan diproksi dengan nilai pengeluaran pembangunan. Data ini diperoleh dari Badan Pusat Statistik (BPS).

\section{Jenis dan Sumber Data}

Jenis data yang diperlukan adalah data sekunder yang meliputi: Data rencana investasi swasta, realisasi investasi swasta, tingkat suku bunga kredit pada bankbank umum, Produk Domestik Bruto (PDB) harga berlaku, dan pengeluaran pembangunan pemerintah tahun 1986-2011. Sumber data tersebut diperoleh dari: diperoleh dari Badan Pusat Statistik (BPS) tahun 1986-2011.

\section{Metode Analisis}

Metode analisis data yang digunakan yaitu: model regresi majemuk. Penggunaan model regresi majemuk ini ditujukan untuk melihat faktor-faktor yang mempengaruhi investasi swasta dalam negeri. Model umum yang digunakan sebagai berikut:

$\mathrm{DI}=\mathrm{f}(\mathrm{SBK}, \mathrm{PDB}, \mathrm{PP})$

Model persamaan fungsional tersebut dijadikan dalam model persamaan regresi yang memuat variabel yang dijelaskan (dependen) InvS dengan variabel yang menjelaskan SBK, PDB, PP, menjadi:

$$
\begin{array}{ll}
\text { InvS }=\beta_{0}+\beta_{1} & \text { SBK }+\beta_{2} \mathrm{PDB}+\beta_{3} \mathrm{PP}+\mu \\
\text { dimana: } & \\
\text { InvS } & =\text { Investasi Swasta } \\
\text { SBK } & =\text { Suku Bunga Kredit } \\
\text { PDB } & =\text { Produk Domestik Bruto } \\
\mathrm{PP} & =\text { Pengeluaran Pemerintah } \\
\beta_{0} & =\text { Intersep } \\
\beta_{1}, \beta_{2}, \beta_{3}, \beta_{4}= & \text { Parameter koefisien variabel bebas } \\
\mu & = \\
& \text { gangguan (disturbance) } \\
& \text { atau kesalahan (error) }
\end{array}
$$

Persamaan tersebut merupakan model yang akan digunakan dalam penelitian dan akan menjelaskan pengaruh variabel independen (bebas) terhadap variabel dependen (terikat). Untuk mendapatkan taksiran parameter maka digunakan teknik OLS (Ordinary Least Square) yang mengikuti asumsi kenormalan BLUE (Best Linear Unbiased Estimator) yaitu penaksir terbaik linear yang tidak bias.

\section{HASIL}

\section{Pengujian Terhadap Pelanggaran Asumsi Klasik Uji Multikolinearitas}

Dari hasil perhitungan nilai tolerance (Tabel 1.) menunjukkan tidak ada variabel bebas yang memiliki nilai tolerance kurang dari $10 \%$ yang berarti tidak ada korelasi antar variabel bebas yang nilainya lebih 
dari $95 \%$. Hasil perhitungan nilai variance inflation factor (VIF) juga menunjukkan hal yang sama tidak ada satu variabel bebas yang memiliki nilai VIF lebih dari 10. Jadi dapat disimpulkan bahwa tidak ada multikolinearitas antar variabel bebas dalam model regresi.

Tabel 1. Uji Multikolinearitas dengan collinearity statistics

\begin{tabular}{ccc}
\hline Variabel & Tolerance & VIF \\
\hline PP & 0,550 & 1.817 \\
PDB & 0,558 & 1.793 \\
SBK & 0,961 & 1.041 \\
\hline
\end{tabular}

\section{Uji Heterokedastisitas}

Pengujian ini bertujuan untuk mendeteksi apakah varians dari kesalahan pengganggu, konstan untuk semua variabel penjelas. Bila ditemukan varians dari kesalahan penggangu tersebut tidak konstan, maka berarti dalam model yang digunakan terdapat gejala heterokedastisitas. Konsekuensi dari adanya heterokedastisitas ini adalah bahwa penaksir OLS tetap tidak bias dan konsisten tetapi tidak efisien. Untuk uji heterokedastisitas dapat dilihat pada Gambar 2. Scatterplot berikut.

\section{Scatterplot}

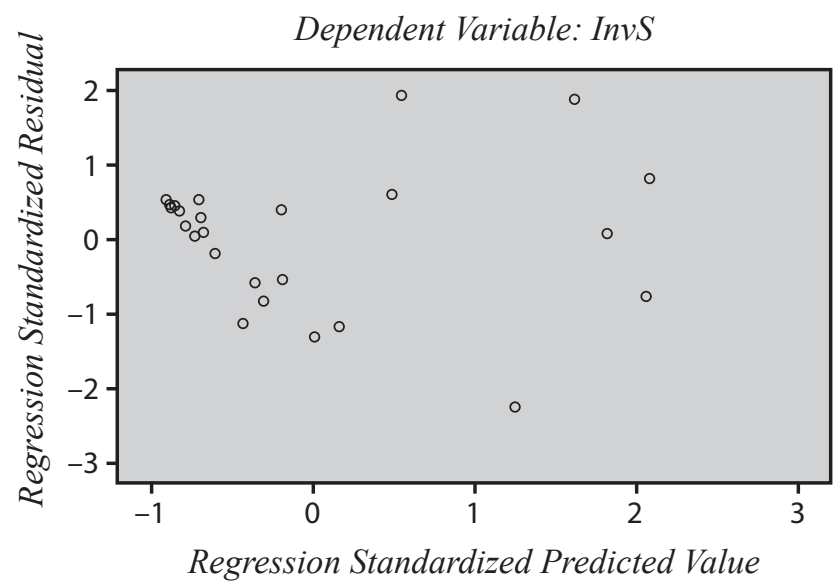

Gambar 2. Scatterplot Uji Heterokedastisitas

Pada Gambar 2. terlihat bahwa residual plot yang terjadi tidak menggambarkan adanya pola tertentu yang sistematis (hubungan linear maupun kuadratik atau bergelombang, melebar kemudian menyempit), namun lebih bersifat acak. (cenderung menyebar), sehingga persamaan regresi yang dipakai dalam penelitian ini dapat memenuhi asumsi homokedastisitas.

\section{Uji Autokorelasi}

Hasil-hasil pengujian autokorelasi dengan menggunakan uji Durbin Watson yang diperoleh dari estimasi model dapat dilihat pada Tabel 2. yaitu sebesar 1,770. Berdasarkan hal tersebut, dengan melihat pada tabel uji DW titik penting diketahui bahwa dl (durbin lower) dan du (durbin upper) pada tingkat penting $\alpha=0,01$ dengan $\mathrm{n}$ sebesar 25 dan $\mathrm{k}=3$ diperoleh nilai $\mathrm{dl}=0,878 \mathrm{dan} \mathrm{du}=1,554$ sehingga nilai DW hitung terletak antara $\mathrm{du}<\mathrm{d}<4-\mathrm{du}$. Dengan demikian dapat disimpulkan tidak terjadi autokorelasi positif atau negatif .

\section{Uji Statistik}

\section{Analisis Uji Secara Parsial (Uji-t)}

Dengan melihat Tabel 2. hasil uji-t dapat di analisis pengaruh masing-masing variabel penjelas terhadap variabel yang dijelaskan secara individu (parsial). Dari Tabel 2. tersebut dapat di kemukakan juga pengaruh masing-masing variabel penjelas terhadap variabel yang dijelaskan secara individu (parsial), sebagai berikut:

1. Pengaruh Pengeluaran pemerintah (PP) terhadap Investasi Swasta (InvS)

Pengujian ini dimaksudkan untuk mengetahui apakah perubahan variabel penjelas yang digunakan pengeluaran pemerintah dalam model regresi secara individu (parsial) berpengaruh terhadap perubahan variabel yang dijelaskan investasi swasta (InvS).

Hasil pengujiannya seperti tampak pada Tabel 2. yaitu diperoleh nilai t hitung untuk investasi swasta terhadap pengeluaran pemerintah adalah sebesar $-2,299$. Pada data penelitian ini menggunakan jumlah n sebesar 25. Kemudian derajat kebebasan $95 \%$ atau dengan kata lain tingkat keyakinan $(\alpha)$ ditetapkan sebesar $(0,05)$, dan degree of freedom (df) dengan rumus $(\mathrm{n}-\mathrm{k})$ sebesar $=21$ sehingga dapat dilihat pada Tabel uji t nilai t Tabel sebesar 2.080. Dari hasil ini dapat disimpulkan bahwa nilai $t$ hitung $>t$ Tabel atau berada pada daerah penolakan $\mathrm{H}_{0}$ atau dengan kata lain terdapat pengaruh signifikan secara parsial antara variabel bebas pengeluaran pemerintah (PP) terhadap variabel yang dijelaskan atau variabel terikat investasi swasta (InvS). 
Tabel 2. Hasil Regresi

\begin{tabular}{cccccc}
\hline Variabel & Koefesien Regresi & Std. Error & Beta & t-statistik & Sig \\
\hline PP & 0,365 & 0,159 & 0,214 & -2.229 & 0,032 \\
PDB & 0,444 & 0,038 & 1,077 & 11.634 & 0,000 \\
SBK & $-3244,355$ & 4271.327 & $-0,054$ & -0.760 & 0,456 \\
\hline
\end{tabular}

R2 $=0,900$

Adj. R2 $=0,885$

F-statistik $=67,717$

Durbin-Watson $=1,770$

2. Pengaruh Produk Domestik Bruto (PDB) terhadap Investasi Swasta (InvS)

Pengujian ini dimaksudkan untuk mengetahui apakah perubahan variabel penjelas yang digunakan Produk Domestik Bruto (PDB) dalam model regresi secara individu (parsial) berpengaruh terhadap perubahan variabel yang dijelaskan investasi swasta (InvS). Hasil pengujiannya seperti tampak pada Tabel 2. yaitu diperoleh nilai t hitung untuk Produk Domestik Bruto (PDB) terhadap investasi swasta (InvS) sebesar 11,634. Pada data penelitian ini menggunakan jumlah $\mathrm{n}$ sebesar 25. Kemudian derajat kebebasan 95\% atau dengan kata lain tingkat keyakinan $(\alpha)$ ditetapkan sebesar 0,05 , dan degree of freedom (DF) dengan rumus (n-k) sebesar $=21$ sehingga dapat dilihat pada tabel uji $\mathrm{t}$ nilai $\mathrm{t}$ tabel sebesar 11,634 (kurva normal sisi sebelah kiri). Dalam penelitian ini dapat disimpulkan nilai t hitung $(11,634)>t$-tabel $(2.080)$ yang berarti ada pengaruh variabel penjelas secara parsial Produk Domestik Bruto (PDB) terhadap variabel yang dijelaskan investasi swasta (InvS).

3. Pengaruh Suku Bunga Kredit (SBK) terhadap Investasi Swasta (InvS)

Pengujian ini dimaksudkan untuk mengetahui apakah perubahan variabel penjelas yang digunakan suku bunga kredit (SBK) dalam model regresi secara individu (parsial) berpengaruh terhadap perubahan variabel yang dijelaskan investasi swasta (InvS). Hasil pengujiannya seperti tampak pada Tabel 2. yaitu diperoleh nilai t hitung untuk suku bunga kredit (SBK) terhadap investasi swasta (InvS) sebesar $(-0,018)$. Pada data penelitian ini menggunakan jumlah n sebesar 25. Kemudian derajat kebebasan 95\% atau dengan kata lain tingkat keyakinan $(\alpha)$ ditetapkan sebesar 0,05, dan degree of freedom (DF) dengan rumus $(n-k)$ sebesar $=21$ sehingga dapat dilihat pada Tabel uji t nilai t-tabel sebesar -0.760 . Dalam penelitian ini dapat disimpulkan nilai t hitung $(-0,760)<$ t-tabel $(2.080)$ yang berarti tidak ada pengaruh signifikan variabel penjelas suku bunga kredit (SBK) secara parsial terhadap investasi swasta (InvS).

\section{Pengujian Secara Bersama-sama (uji-F)}

Dengan melihat Tabel 2. hasil uji-F dapat di analisis pengaruh variabel penjelas terhadap variabel yang dijelaskan secara bersama-sama.

Dari Tabel 2. diperoleh nilai $\mathrm{F}$ hitung sebesar 62,717 Pada data penelitian ini menggunakan jumlah n sebesar 25. Kemudian derajat kebebasan 95\% atau dengan kata lain tingkat keyakinan $(\alpha)$ ditetapkan sebesar 0,05 , dan degree of freedom (DF) for numerator (N1) sebesar (k-1) $=3$ serta (DF) for denumerator $(\mathrm{N} 2)$ sebesar $(\mathrm{n}-\mathrm{k})=21$ sehingga dapat dilihat pada tabel uji $\mathrm{F}$ nilai $\mathrm{F}$ tabel sebesar: 2,66. Dalam penelitian ini dapat disimpulkan nilai F hitung $(62,717)>F$ tabel $(2,66)$ yang berarti ada pengaruh variabel independen secara bersama-sama pengeluaran pemerintah (PP), produk domestik bruto (PDB), suku bunga kredit (SBK) terhadap variabel dependen investasi swasta (InvS).

\section{Pengujian Koefisien Determinasi (Uji $\mathbf{R}^{\mathbf{2}}$ )}

Berdasarkan hasil regresi, diperoleh koefisien determinasi sebesar $90,0 \%$ yang berarti nilai koefisien determinasi pada persamaan estimasi investasi swasta sekitar $90,0 \%$ variasi investasi swasta dapat dijelaskan oleh variabel bebasnya, sedangkan sisanya $(10 \%)$ dijelaskan oleh variabel lain yang belum teramati. 


\section{PEMBAHASAN}

Variabel Pengeluaran Pemerintah memiliki hubungan yang positif dengan selisih rencana investasi dengan realisasinya. Artinya adanya kenaikan pengeluaran pemerintah akan menambah rencana investasi swasta dalam negeri. Hal ini sejalan dengan teori-teori tentang investasi dan sejalan dengan hasil dari beberapa penelitian sebelumnya. Penelitian di negara Pakistan yang meneliti pengaruh belanja pemerintah dan ketidakpastian makro ekonomi terhadap investasi swasta di sektor jasa selama periode 1972-2005 menunjukkan hasil bahwa belanja pemerintah dan tingkat suku bunga mempengaruhi investasi swasta pada sektor jasa di Pakistan (Ahmad, Imtiaz, dan Qayyum, Abdul, 2008). Penelitian-penelitian lainnya juga memperlihatkan adanya hubungan positif antara pengeluaran pemerintah dengan investasi swasta (Sakr, 1993 Haque, Husain, dan Montiel, 1991; Naqvi, 2002). Selain itu Mehmood dan Sadiq (2010) dalam artikel ilmiahnya menjelaskan bahwa pengeluaran atau belanja pemerintah, merupakan sumber finansial yang tepat yang dapat meningkatkan investasi swasta, kesempatan kerja, peningkatan sumber daya manusia melalui pendidikan dan kesehatan, sehingga dapat mengurangi tingkat kemiskinan di Pakistan.

Variabel Produk Domestik Bruto (PDB) mempunyai pengaruh postif yang signifikan terhadap investasi swasta. Hal ini berarati semakin tinggi tingkat PDB maka para investor akan meningkatkan realisasinya untuk memenuhi permintaan pasar terhadap barang dan jasa. Hal ini sejalan dengan pendapat Acosta (2005) yang menjelaskan bahwa PDB dapat dipakai sebagai proxy dari variabel permintaan agregat yang merupakan faktor penentu investasi swasta. Tingkat pendapatan nasional atau regional yang tinggi akan memperbesar pendapatan masyarakat, dan selanjutnya pendapatan masyarakat yang tinggi tersebut akan memperbesar permintaan akan barangbarang dan jasa-jasa, maka keuntungan perusahaan akan bertambah tinggi dan ini akan mendorong dilakukannya investasi. Dengan demikian dapat diketahui adanya kemungkinan perubahan investasi yaitu jumlah investasi akan berubah apabila terdapat peningkatan jumlah pendapatan. Pembangunan ekonomi melibatkan kegiatan-kegiatan produksi di semua sektor-sektor ekonomi. Dengan adanya kegiatan produksi, maka terciptalah kesempatan kerja dan pendapatan masyarakat meningkat, yang selanjutnya menciptakan permintaan di pasar barang dan jasa. Berkembangnya pasar juga berakibat pada meningkatnya volume produksi, kesempatan kerja dan pendapatan di dalam negeri meningkat, maka terciptalah pertumbuhan ekonomi.

Penelitian lainnya juga menujukkan adanya hubungan positif antara investasi swasta dengan PDB (Choe, 2003; Quin, Cagas, Quising dan He, 2006). Penilitian Al-Iriani (1988) menyimpulkan bahwa di negara-negara GCC (Gulf Cooperation Council) bahwa adanya hubungan kausalitas dua arah (bidirection causality) antara Gross Domectic Product dengan investasi asing langsung (foreign direct investment).

Bagaimana hubungan antara tingakt suku bunga dengan investasi swasta di Indonesia, berdasarkan hasil penelitian menunjukkan bahwa bahwa tingkat suku bunga sebagai bagian dari biaya investasi (cost of capital) merupakan variabel yang cukup penting dalam pengambilan keputusan untuk berinvestasi. Semakin tinggi tingkat suku bunga maka biaya investasi akan semakin besar dan sebaliknya. Para investor hanya akan melakukan penanaman modal jika memiliki harapan bahwa investasi yang dilakukan akan memberikan tingkat pengembalian (rate of return) yang lebih besar dari biaya yang dikeluarkan. Dalam konteks inilah keberadaan tingkat suku bunga penting untuk dipertimbangkan. Dalam artikel Gul dan Ekinci (2006) menjelaskan bahwa perubahan tingkat suku bunga akan berpengaruh secara negatif terhadap investasi dalam dua arah. Pertama peningkatan suku bunga menyebabkan pengaruh negatif terhadap nilai present value dari hasil investasi. Kedua, peningkatan suku bunga menyebabkan peningkatan biaya pinjaman, sehingga akan menurunkan permintaan kredit untuk pembiayaan investasi.

Penelitian lainnya yang membahas tentang hubungan antara tingkat suku bunga dan investasi swasta di Venezuela adalah penelitian Lugo (2003) yang mengestimasi efek dari perubahan dalam suku bunga riil terhadap pertumbuhan investasi swasta. Hasil penelitian tersebut menunjukkan bahwa adanya efek peningkatan suku bunga riil memberikan dampak negatif pada investasi swasta. 


\section{KESIMPULAN}

Variabel tingkat suku bunga, pengeluaran pemerintah, dan PDB secara bersama-sama sangat berpengaruh terhadap investasi swasta di Indonesia. Faktor suku bunga akan memberi pengaruh negatif terhadap investasi swasta Indonesia, sedangkan Produk Domestik Bruto (PDB) akan memberi pengaruh positif terhadap investasi, demikian juga dengan variabel pengeluaran pemerintah memberikan pengaruh positif terhadap investasi swasta di Indonesia. Keberadaan tingkat suku bunga yang berdampak negatif terhadap investasi swasta di Indonesia perlu ditindak lanjuti dengan upaya-upaya pemerintah dan pihak perbankan guna merumuskan tingkat suku bunga yang ideal sehingga tidak menimbulkan dampak yang merugikan terhadap investasi yang direalisasikan. Tingkat pendapatan nasional atau regional yang tinggi akan memperbesar pendapatan masyarakat, dan selanjutnya pendapatan masyarakat yang tinggi tersebut akan memperbesar permintaan akan barang-barang dan jasa-jasa, maka keuntungan perusahaan akan bertambah tinggi dan ini akan mendorong dilakukannya investasi. Variabel pengeluaran pemerintah memiliki hubungan yang positif dengan investasi. Berdasarkan hasil penelitian tersebut, maka untuk mengurangi gap investasi maka pengeluaran pemerintah harus dilakukan secara lebih efisien, terutama untuk pengeluaran pemerintah yang dibiayai dari sektor pajak agar lebih menarik investor. Pengeluaran pemerintah juga harus lebih efektif terutama diarahkan untuk membiayai pembangunan yang dapat menunjang kegiatan investasi di sektor riil menjadi lebih meningkat.

\section{DAFTAR PUSTAKA}

Acosta, Pablo. 2005. Short and Long Run Determinants of Private Investment in Argentina. Journal of Applied Economics, VIII(2): 389-406.

Al-Iriani, Mahmoud. 1998. Foreign Direct Investment and Economic Growth in the GCC Countries: A Causality Investigation Using Heterogeneous Panel Analysis. Journal of Economic Dynamics and Control, 12: 255-296.

Ahmad, Imtiaz and Qayyum, Abdul. 2008. Effect of Government Spending and Macro-Economic Uncertainty on Private Investment in Services Sector: Evidence from Pakistan. European Journal of Economics, Finance and Administrative Sciences, 11(September): 84-96.
Bayai, Innocent and Davis Nyangara. 2013. An Analysis of Determinants of Private Investment in Zimbabwe For The Period 2009-2011. International Journal of Economics and Management Sciences, 2(6).

Boediono. 1992. Teori Pertumbuhan Ekonomi, Seri Sinopis Pengantar Ilmu Ekonomi. Yogyakarta: BPFE.

Choe, J. I. 2003. Do Foreign Direct Investment and Gross Domestic Investment Promote Economic Growth?. Review of Development Economics, 7(1), 44-57.

Fielding, David. 1997. Adjustment Trade Policy and Investment Slumps: Evidence form Africa. Journal of Development Economics, 52.

Greene, Joshua and Delano Villanueva. 1991. Private Investment in Developing Countries: an Empirical Analysis. IMF Staff Papers, 38.

Gul, Ekrem and Ekinci, Aykut. 2006. The Causal Relationship Between Nominal Interest Rates and Inflation: The Case of Turkey. Scientific Journal of Administrative Development, 4: 54-69.

Haque, N., Husain, A., and P. Montiel. 1991. An Empirical "Dependent Economy" Model for Pakistan. IMF Working Papers.

Iswandoro, Pramono. 1994. Peluang Investasi di Daerah Istimewa Yogyakarta Dalam Rangka Peningkatan Pertumbuhan Ekonomi Daerah, Kerjasama PPE-FE UGM dengan BI Yogyakarta.

Kodoatie, Johanna Maria. 1998. An Analysis of Foregin Direct Investment in Indonesia (19711994). Media Ekonomi dan Bisnis, X(1-2).

Lugo, Omar A. M. 2003. The Differential Impact of Real Interest Rates and Credit Availability on Private Investment: Evidence from Venezuela. BIS Papers, (35): 501 - 537.

Mehmood, Rashid and Sadiq, Sara. 2010. The Relationship between Government Expenditure and Poverty: A Cointegration Analysis. Romanian Journal of Fiscal Policy, 1(1): 29-37.

Naqvi, Neveed, H. 2002. Crowding-in or Crowdingout? Modelling the Relationship between Public and Private Fixed Capital Formation Using Cointegration Analysis: The Case of Pakistan 19642000. The Pakistan Development Review, 41(3): 255-276.

Ouattara, B. 2005. Modelling the Long Run Determinants of Private Investment in Senegal. CREDIT Research Paper No 04/05, Centre for Research in Economic Development and International Trade, University of Nottingham. 
Qin, D. et al. 2006. How Much Does Investment Drive Economic Growth in China? Journal of Policy Modeling, 28(7), 751-774.

Radianto, Elia. 1995. Spesifikasi Dinamis, Model Investasi Jangka Panjang; Sebuah Studi Kasus di Maluku. Jurnal Ekonomi dan Bisnis Indonesia, 10.

Sakr, Khaled. 1993. Determinants of Private Investment in Pakistan. IMF Working Paper, 93(30).

Sasana, Hadi. 2008. Analisis Faktor-Faktor yang Mempengaruhi Investasi Swasta di Jawa Tengah. Jurnal Ekonomi dan Kebijakan, 1(1).
Sukirno, Sadono. 1994. Pengantar Teori Makro Ekonomi. Jakarta: PT Raja Grafindo Persada.

Todaro, Michael P. 2000. Pembangunan Ekonomi di Dunia Ketiga, Jakarta: Erlangga.

Wai T. U. and Wong C. H. 1982. Determinants of Private Investment in Developing Countries. Journal of Development Studies, 19.

Zaris, Roeslan. 1987. Perspektif Daerah Dalam Pembangunan Nasional. Jakarta: LPFE UI. 